\title{
Documents as Weapons: The Uses of a Dictatorship's Archives
}

\author{
Elidor Mëhilli*
}

Elidor Mëhilli, Hunter College of the City University of New York, Department of History, 695 Park Avenue, New York, NY 10065, USA

*elidor.mehilli@hunter.cuny.edu

Close to thirty years after the fall of the Berlin Wall Albania remains a blind spot in the literature on twentieth-century socialism. International histories of the Cold War continue to 'de-centre' Europe, and the focus increasingly shifts to relations between big powers and the so-called Third World. But this recent euphoria of 'the global' has also tended to obscure how a small European country can remain terra incognita for so long. In much of the former communist world, the socalled 'archival revolution' of the 1990s has helped produce a now large body of literature. Such a process has been slow and complicated in Albania. This essay begins by asking why. It first offers an overview of Albanian-language historical work from roughly the last two decades, placing it alongside other relevant contributions in English, German, Italian and French, to highlight trends and suggest possible analytical paths.

My thoughts are organised around the problem of the country's archives, which took many years to become available to historians. Shrouded in mystery, communist era archives have often become places of political controversy over major themes like the Second World War and the origins of communist power. This essay argues for making archives objects of analysis, too. After surveying how authors have and have not approached the party-state's sources, it offers a history of archiving as an example of state led centralisation. The push to centralise archives coincided with a period in which Albania's regime sought to make sense of shifting foreign alliances: from a dedicated ally of the Soviet Union to an anti-Soviet voice during the revolutionary 1960s. Rather than as depositories of hidden truths, archives emerge as part of a larger project to define the state and discipline its past. They can shed much light on the domestic landscape of this period, but they can also offer new insights into how processes of nationalisation have been deeply intertwined with internationalist imperatives.

\section{Blind Spots}

Founded in 1941, the Communist Party of Albania (renamed Party of Labour, after consultations with Stalin, seven years later) was initially bound to neighbouring Yugoslavia, which provided tactical advice. Yugoslav advisors immersed themselves in planning affairs after Albania's liberation, an arrangement initially also supported by Stalin. Within a few years, however, the Soviet leader had grown impatient with his Yugoslav counterpart, Josip Broz Tito. During the SovietYugoslav rift in 1948, Albania's cunning party chief Enver Hoxha saw an opportunity to escape from Yugoslav dependency, professing loyalty to the Kremlin. Purges of so-called pro-Yugoslav individuals ensued, followed by years of intense borrowing from the Soviet Union: desperately

\footnotetext{
Thanks to Emily Greble for commissioning this essay and for providing detailed feedback, and to the anonymous reviewer for a sharp reading, which helped me bring discipline to the text. I presented some of these ideas at the conference 'Mes apatisë dhe nostalgjisë: Kujtesa publike dhe private për komunizmin në Shqipërinë e sotme', organised by the Institute for Democracy, Media and Culture in Tirana, Albania, in November 2017. Thanks to Idrit Idrizi and Jonila Godole. Research funding was generously provided by the PSC-CUNY Research Awards and the Hunter College Presidential Travel Awards.

(C) Cambridge University Press 2019.
} 
needed loans, industrial installations, a flurry of technical advisers and scholarships for promising youths. While the regime pursued a war against widespread illiteracy, Russian language courses popped up in workplaces and schools. In a country of peasants, the ruling party set out to build socialism.

But relations between the Albanian and Soviet parties grew uneasy when Stalin's successor, Nikita Khrushchev, experimented with changes in foreign policy. Hoxha paid lip service to calls for reform but grew increasingly convinced that Khrushchev's de-Stalinisation was a formula for self-destruction. During the dramatic summer of 1960, as Sino-Soviet disagreements erupted, he saw yet another opportunity to escape the pressures of a bigger power. Backing Beijing in the dispute, Albania's party boss denounced Khrushchev as a traitor to Leninism. There could be no coexistence with capitalism, he declared, continuing to heap praise on Stalin, whom he credited with saving Albania from Yugoslav annexation in the 1940s. Such zigzags allowed a hardline regime in one corner of Southeastern Europe to project itself as the saviour of the nation in the face of more powerful foreigners. They also encouraged repeated purges of imaginary internal enemies alleged to have conspired against the state. In the 1960s relations with Beijing also had their ups and downs. But throughout all of this the country's regime projected a sense of inevitability to its path - the vicious battles it had waged morphed into a narrative of righteousness. ${ }^{1}$

Unlike elsewhere in the Eastern Bloc, state-directed repression did not abate. And so it has been particularly important to study that long-term legacy of state violence. Such has been the pursuit of the Institute for the Study of the Crimes and Consequences of Communism (Instituti $i$ Studimeve për Krimet dhe Pasojat e Komunizmit), which has issued numerous publications, focusing chiefly on political prisoners, internment camps, biographical data and testimonies. ${ }^{2}$ Much of the rest of Albanian-language historical scholarship on this period has also been domestic-oriented in scope. The country's flagship professional journal (Studime historike) first appeared under the communist regime in $1964 .^{3}$ It continues to be published by the Institute of History, a state-funded entity. In recent years it has churned out occasionally valuable, if typically narrowly conceived, research on the post-Second World War era. But one problem with Studime is the fact that it covers all periods of historical inquiry - one recent issue included articles on Christianity before and after the Edict of Milan (313 AD), eighteenth-century waqfiya (Ottoman era foundation deeds) in the city of Berat and great power involvement in the Balkans in 1914. This means that any one issue might have nothing at all on the post-1945 period.

In the absence of another professional journal dedicated exclusively to contemporary history, more innovative scholarship on the communist period has appeared in the multi-disciplinary

\footnotetext{
1 A welcome recent dissertation shows how Albanian activists pursued objectives within a multinational framework throughout the first half of the century, reinstating Ottoman era precedents and associations to the history of interwar activism and communist organisation. Lejnar Mitrojorgji, 'Between Nation and State: Albanian Associations from Ottoman Origins to a Communist Party, 1880-1945’, PhD dissertation, University of Maryland, 2016.

2 Among others, see an ongoing anthology: Azem Qazimi and Çelo Hoxha, eds., Fjalor enciklopedik $i$ viktimave të terrorit komunist, 6 volumes (Tirana: ISKPK, 2012-2017). An Albanian version of the Black Book of Communism has highlighted thousands of executed individuals whose graves remain unknown. Agim Musta, Libri i zi i komunizimit shqiptar (Tirana: Naim Frashëri, 2007).

3 My focus here is on recent scholarship only. A study of the longer-term development of Studime historike and the historical profession's role under socialism would be a useful subject to pursue separately. See Marenglen Verli, '50-vjet revistë 'Studime historike' (1964-2014)', Studime historike 3-4 (2014), 281-8. The institutional framework for conducting professional historical research is itself a legacy of central planning. The Institute of Studies, started in 1946, had a section on history. It was later renamed Institute of Sciences. When the Academy of Sciences was established in the 1970s, the Institute of History was attached to it. In recent years the state's role in organising research (including the uncertain future of the Academy of Sciences and the formal place of Albanian Studies within public funding schemes) has been a source of contention. Currently, the Institute has been placed under The Center for Albanological Studies (Qendra e Studimeve Albanologjike), alongside sections on archaeology, linguistics and literature and popular culture. A representative example of the Institute's collective effort is Historia e popullit shqiptar: në katër vëllime, 4 vols. (Tirana: Toena/Akademia e Shkencave, 2002-8).
} 
journal Përpjekja, started in 1994 by Fatos Lubonja, one of the country's foremost public intellectuals. ${ }^{4}$ Përpjekja is unencumbered by the rigidities and infighting that has characterised the Institute of History, where an older generation of historians, who came of age under socialism, have often clashed with a younger cohort. And so Përpjekja has been successful in attracting younger authors who are also able to work in various foreign languages. The journal produces thematic issues, which give readers a better sense of the intellectual contours of the published work. Finally, it is also the rare venue where Albanian and foreign scholars publish alongside one another, which has had the effect of making Studime seem all the more parochial and outdated. ${ }^{5}$

Much of the Albanian-language secondary literature on the post-1945 period consists of general overviews, with a sharp focus on political history. Unsurprisingly, the National Liberation War (Lufta Nacional-Çlirimtare) continues to be a central topic in historical debates. It is in wartime dynamics, after all, that historians have sought the roots of the communist regime. But as important as the war is, longstanding questions in Albanian-language historiography seem to have turned into dead ends. For example, authors continue to approach archives for clues into the vexing nationalism question: was long-serving party boss Enver Hoxha a nationalist, or not? Did his rejection of bigger states like Yugoslavia and, later on, the Soviet Union signal an enduring nationalism that supposedly trumped his ideology? Was he, instead, an opportunist? (As if these things had to be mutually exclusive.) Depending on one's position on these questions, the problem of Kosovo's fate under Yugoslavia can serve as ammunition to prove either viewpoint. Showing Hoxha to have been 'anti-national' (anti-kombëtar) has been understood to go some way towards exposing communism as alien to the nation's destiny, which contemporary authors have been at pains to define as 'European' ${ }^{6}$

Historians have thus pursued tedious polemics on whether the National Liberation War could also be thought of as a civil war, such that foreigners (and their domestic stooges) might be shown to have 'corrupted' nationalist causes under the guise of internationalism (which is imagined as a 'fig leaf covering nefarious geopolitical plans in Southeastern Europe). Such exchanges have shown a poor understanding of how the literature on the Second World War has evolved outside the country. They have revealed an uncritical attitude towards archives, as if the answers to such questions might derive from newly discovered sheets of paper in a basement. In

\footnotetext{
4 In the 1970s Lubonja was imprisoned on charges on 'agitation and propaganda'. A memoir of his prison years has been translated into English: Fatos Lubonja, Second Sentence: Inside the Albanian Gulag (London: I.B. Tauris, 2009). Todi Lubonja, Fatos' father, headed the radio and television agency in the early 1970s when he was purged as part of a sweeping cultural offensive. He also later published a memoir detailing his own prison years. Todi Lubonja, Nën peshën e dhunës: ribotim, 2nd. ed. (Tirana: Mësonjëtorja, 1998). So did Liri Lubonja, Todi's wife, who endured internment during the imprisonment of her husband and son. Liri Lubonja, Larg dhe mes njerëzve: kujtime internimi, 1973-1990 (Tirana: Dora D'Istria, 1995). This makes it uniquely possible to view the state directed repression of the 1970s and 1980s through the lens of one family's written testimonies.

5 As an example, one 2014 issue of Përpjekja (Nr. 32-33), titled 'Current Studies and New Approaches to the History of 20th Century Albania', featured essays on socialist era industrialisation (Visar Nonaj), demographics (Gjergj Erebara) and the politics of state-sanctioned atheism (Egin Ceka).

6 Many of the so-called polemics have come with select archival documents attached. For example, Ndreçi Plasari and Luan Malltezi, Politikë antikombëtare e Enver Hoxhës: Plenumi i 2-të i KQ të PKSH, Berat, 23-27 nëntor 1944: dokumente (Tirana: Drejtoria e Përgjithshme e Arkivave, 1996). See also Uran Butka, Dritëhije të historisë: (polemikë me Kristo Frashërin) (Tirana: Maluka, 2012); Lufta civile në Shqipëri: 1943-1945 (Tirana: ISKPK, 2015); Mukja - shans i bashkimit, peng i tradhtisë (Tirana: Naim Frashëri, 1998). Butka, for example, has taken issue with the work of Kristo Frashëri, who was one of the principal historians of the left in Albania and co-author of some of the country's textbooks. Among Frashëri's more recent works, see Historia e qytetërimit shqiptar: nga kohët e lashta deri në fund të Luftës së Dytë Botërore (Tirana: Akademia e Shkencave e Shqipërisë, 2008); Mbi historinë e Ballit Kombëtar: (vështrim kritik) (Tirana: Dudaj, 2012); Kongresi i Përmetit (24-28 maj 1944): vështrim historik dhe burime dokumentare (Tirana: Akademia e Shkencave, 2015); Shqipëria në Konferencën e Paqes, Paris 1946: (vështrim historik) (Tirana: Akademia e Shkencave e Shqipërisë, 2015). For an overview of Frashëri's role in Albanian historiography, see Michael Schmidt-Neke, 'Kristo Frashëri (19202016)', Südost-Forschungen, 74, 1 (Aug. 2015): 208-10.
} 
fact, these are problems of historical interpretation and, above all, imagination. But wartime archives continue to be places of controversy because that is where the political stakes are. Whereas socialist era historians spent decades crafting a heroic narrative around the war, the effort to 'expose' the war as a form of national betrayal is seen as a way of 'delegitimising' the communist regime. By comparison, post-war era state archives are far less explored, though there has been some progress. ${ }^{7}$ The outcome has been a remarkably thin archive based literature on the post-war years, particularly work that systematically combines a view of politics with everyday life or that considers the longer-term exercise of state power through the development of institutions, practices and worldviews. ${ }^{8}$

Though my focus here is on historical research, and especially on Albanian-language scholarship, it is important to make two clarifications. First, relevant work on the post-1945 period has emerged in several other languages and across national research traditions. There are longstanding Albanian studies-focused clusters of various sizes in Austria, Italy, Germany, France, the United Kingdom and the United States. They have been sites of important multidisciplinary work though vanishing funding and research positions have affected some of them. International cooperation used to be sporadic but it has also increased. ${ }^{9}$ Albania is a small place. Its language is not easy to learn. In the age of global history (and evaporating area studies positions), studying a small place carries some professional risk. There are, however, some encouraging signs in Tirana and Prishtina. ${ }^{10}$ And there is a growing cohort of Western-based Albanian-speaking scholars - a reflection of the country's diasporic reality today - who might serve as a kind of bridge between national traditions.

Secondly, some of the more perceptive analyses of the dictatorship have emerged in other disciplines, including in sociology and anthropology. The US-based sociologist Besnik Pula has brilliantly analysed the micro-dynamics of law and the administrative transformation of Albanian lowland peasantry - as compared to highland society and pre-socialist centralisation - on

\footnotetext{
7 Examples of general twentieth-century texts include Valentina Duka, Histori e Shqipërisë, 1912-2000 (Tirana: Kristalina, 2007) and Kastriot Dervishi, Historia e Shtetit shqiptar 1912-2005 (Tirana: 55, 2006). Specifically on the post-war period, see Hamit Kaba, Shqipëria në rrjedhën e luftës së ftohtë (studime dhe dokumenta) (Tirana: Botimpex, 2007) and Shqipëria dhe të mëdhenjtë: nga Lufta e Dytë Botërore në Luftën e Ftohtë (Tirana: Klean, 2015). Ana Lalaj’s Pranvera e rrejshme e pesëdhjetegjashtës: vështrim studimor mbi Konferencën e Tiranës dhe dokumente për protagonistët e saj (Tirana: Infbotues, 2015) examines the 1956 challenge of de-Stalinisation by combining attention to domestic pressures with foreign policy imperatives. Lalaj has also published extensively on Albania's shifting Cold War era alliances and on the wartime period. For example, see her Dosjet e luftës (histori) (Tiranë: Toena, 2014). Among a younger cohort, more recent specialised studies include Gjon Boriçi, Marrëdhëniet shqiptaro-kineze në Luftën e Ftohtë, 1956-1978 (Tirana: Mirgeeralb, 2016) and Enver Bytyçi, Shqipëri-Kinë: dështimi i një bashkëjetese; historia e marrëdhënieve midis Tiranës e Pekinit gjatë periudhës së komunizmit (Tirana: ISES, 2014), both focused on Sino-Albanian relations.

8 An exception to this point is recent work on socialist morality and the creation of a 'new man'. See, for example, Idrit Idrizi, 'Der Neue Mensch in der Politik und Propaganda der Partei der Arbeit Albaniens in den 1960er Jahren', SüdostForschungen, 69/70 (2010/2011): 252-83 and 'Herrschaft und Alltag im albanischen Spätsozialismus (1976-1985)', PhD dissertation, Universität Wien, 2016. The latter is forthcoming as a monograph in the series 'Südosteuropäische Arbeiten' sponsored by the Leibniz-Institut für Ost- und Südosteuropaforschung. In Albanian, see Albert Nikolla, Njeriu $i$ ri shqiptar: ndërmjet moralit komunist dhe krizës së tranzicionit (Tirana: Onufri, 2012).

9 An international conference in Albanian Studies convened in London in 1999, resulting in a publication: Stephanie Schwandner-Sievers and Bernd Jürgen Fischer, eds., Albanian Identities: Myth, Narratives and Politics (Bloomington: Indiana University Press, 2002). A second international conference ('Practices, Materiality, Places and Temporality: New Approaches in Albanian Studies') took place in Tirana in October 2018. In between, a summary of foreign-language scholarship was published in Oliver Jens Schmitt und Eva Anne Frantz, eds., Albanische Geschichte. Stand und Perspektiven der Forschung (Munich: Oldenbourg, 2009). Few of the contributions, however, specifically deal with the communist period.

10 I have in mind the work of younger Prishtina-based historians like Mrika Limani, for example, who are well placed to investigate Yugoslav-Albanian relations from a fresh perspective. In Tirana, recent years have seen interdisciplinary conferences convened by the Faculty of Social Sciences and the University of Tirana. There have also been efforts to make archival documents accessible to schools. For example: Idrit Idrizi, Jonila Godole, and Fatmiroshe Xhemalaj, eds., Komunizmi përmes dokumentesh arkivore. Represioni në periudhën e vetizolimit (Tirana: Filara, 2017).
} 
the eve of communist power. ${ }^{11}$ The Tirana-based political scientist Enis Sulstarova, one of the most imaginative voices of the last decade in Albanian-language scholarship, has mined works of fiction to argue about national forms of self-fashioning under socialism. Based on ethnographic work, US-based cultural anthropologist Smoki Musaraj has analysed food queues as a temporal regime in late socialism, as well as the informal practices of receiving the 'capitalist' signal of Italian television. ${ }^{12}$ Arbër Shtëmbari and Georgia Kretsi delved into the crucial biografitë (institutional biographies) that permeated power relations between individuals, families and the state. ${ }^{13}$ Ardian Vehbiu's study of the linguistic strategies of the dictatorship remains seminal, as does his longstanding contribution through a popular blog attracting some of the best writing in the Albanian language. ${ }^{14}$

A considerable body of work has also developed around the practices of ethnography under socialism, illustrating how the state created a framework for advancing knowledge about 'national culture'. ${ }^{15}$ This is most evident in the example of state-funded studies of 'people's culture' (kultura popullore), but one can also imagine worthy studies of archaeology, linguistics and vernacular forms in architecture as a reflection of the imperative to integrate a national spirit (fryma kombëtare) in construction. Fundamentally, the entire small industry of studime albanologiike will have to confront the problem that it is a product of the socialist state's investment in a specific framing of what constitutes national culture, as made evident in the work of Francebased social anthropologist Albert Doja and the scholar of international studies Enika Abazi, who have written about the official uses of folklore. ${ }^{16}$ A history of studime albanologike as a state project can demonstrate the evolving concerns of a powerful but insecure regime, especially in light of a greater political retreat by the late 1970 s. $^{17}$

11 Besnik Pula, 'State, Law and Revolution: Agrarian Power and the Nation-State in Albania', PhD dissertation, University of Michigan, 2011. Pula has been at the forefront of reviving an institutional framework for Albanian studies in the United States.

12 Smoki Musaraj, 'Alternative Publics: Reflections on Marginal Collective Practices in Communist Albania', in Andreas Hemming, Gentiana Kera and Enriketa Pandelejmoni, Albania: Family, Society and Culture in the 20th Century (Zürich Lit, 2012), 175-86. The study of 1980s and 1990s mental mapping across the Adriatic can go both ways. In 1991 Italy was also confronted with the 'discovery' of Albania, as refugees showed up ashore. This history serves as a reminder that the Mediterranean turned into a 'crisis zone' well before the Syrian Civil War of the 2010s. Ardian Vehbiu and Rando Devole, La scoperta dell'Albania: gli albanesi secondo i mass media (Milano: Paoline, 1996).

13 Arbër Shtëmbari, 'La biographie en Albanie sous le régime communiste', MA thesis, Université de Limoges, 2010; Georgia Kretsi, "Good and Bad Biography": The Concept of Family Liability in the Practice of State Domination in Socialist Albania', in Ulf Brunnbauer, Andreas Helmedach and Stefan Troebst, eds., Schnittstellen: Gesellschaft, Nation, Konflikt und Erinnerung in Südosteuropa: Festschrift für Holm Sundhaussen zum 65. Geburtstag (Munich: Oldenbourg, 2007).

14 Ardian Vehbiu, Shqipja totalitare: tipare të ligjërimit publik në Shqipërinë e viteve 1945-1990 (Tirana: Çabej, 2007); 'Peizazhe të fjalës', www.peizazhe.com (last visited 8 Oct. 2018).

15 Examples include: Nebi Bardhoshi, 'The Ethnography of Law in a Dictatorial Situation', in Aleksandar Boškovic and Chris Hann, eds., The Anthropological Field on the Margins of Europe, 1945-1991 (Zurich: Lit Verlag, 2013), 175-90; Olsi Lelaj, 'Një analizë kritike e studimeve etnografike shqiptare mbi shoqërinë e "real socializmit" në Shqipëri', Kultura Popullore, 1-2 (2011), 199-224 and 'Koncepti i kulturës, etnografia shqiptare dhe situata diktatoriale: Një analizë kritike', Kultura Popullore, 1-2 (2013), 115-32. Studies of socialist ethnography can also provide insights on the persistent urban/rural divide under socialism. See Armanda Hysa, 'L'ethnographie de la période communiste et l'étude de la ville', Ethnologie française, 166, 2 (2017), 217-28.

16 Enika Abazi and Albert Doja 'From the Communist Point of View: Cultural Hegemony and Folkloric Manipulation in Albanian Studies under Socialism', Communist and Post-Communist Studies, 49, 2 (2016), 163-78. See also Eckehard Pistrick, Performing Nostalgia: Migration Culture and Creativity in South Albania (Abingdon: Routledge, 2016), 35-. More broadly on the relationship between socialist politics and varieties of music, see Nicholas Tochka, Audible States: Socialist Politics and Popular Music in Albania (New York: Oxford University Press, 2016).

17 Adopting a transnational lens can be revealing here, as with the example of 1950s East German-Albanian cooperation in musicology. Wilfried Fiedler, 'Die deutsch-albanische Expedition von 1957 und ihre Bedeutung für die deutschsprachige Albanologie', in Eckehard Pistrick, ed., Deutsch-albanische Wissenschaftsbeziehungen hinter dem Eisernen Vorhang (Wiesbaden: Harrassowitz Verlag, 2016), 17-26. 
Recent work has tended to focus on the second half of the communist period, perhaps a reflection of the possibility to conduct oral history and the wider published secondary source base available. Analyses obsess over issues of identity (as did the communist regime). This is also the lens through which much of Western scholarship has typically approached Albania's socialism: as a form of fierce nationalist expression. ${ }^{18}$ The political breaks with Belgrade, Moscow and Beijing have served to highlight this idea of a supposed staunch nationalism prevailing over alternatives, which dovetails with the way the regime saw itself. And yet, some of the recent work mentioned above shows that micro-level studies can help cast the socialist period from new perspectives: without succumbing to a totally divorced view of domestic politics from the international stage in which the state participated, and without assuming the inevitability of some already-there nationalist vision. There have always been many ways to be Albanian, just as there have been competing visions for the country's place in the international system. MarxismLeninism offered a path to claim such a place.

As revelatory as archives can be, we also know - through case studies ranging from the pre1990s Soviet Union to the modern Middle East - that historiography can develop in imaginative ways in their absence. ${ }^{19}$ So it is worthy to reflect on what archives cannot do. It is similarly important to explore unofficial archives, moving beyond what the party-state has left behind. ${ }^{20}$ We should consider how memoirs, rather than archive-based accounts, have raised some of the more probing questions about social dynamics under Hoxha's regime. ${ }^{21}$ Over more than four decades, a significant number of educated individuals ended up as political prisoners: from the small pre-war Central Europe educated intellectual cohort, or even individuals with living memory of Ottoman era administration, to Comintern-connected activists who fell victims to periodic purges, and all the way to the apparatchiks and youths charged with so-called anti-state crimes in the 1970s. They coexisted with others locked up for non-political crimes, such that prison turned into a kind of education, too. The outcome has been a flood of published recollections, attesting to prison life as daily humiliation but also as a form of socialisation: history lessons, gossip about the party and long discussions about world affairs. Purged high-level officials, after all, had been witnesses to crucial events in the party's past, describing them in

18 The emphasis of nationalism in Hoxha's ideological outlook is evident in Bernd J. Fischer, 'Enver Hoxha and the Stalinist Dictatorship in Albania', in Fischer, ed., Balkan Strongmen: Dictators and Authoritarian Rulers in South Eastern Europe (West Lafayette: Purdue University Press, 2007), 239-68. As a research and funding framework, nationalism continues to dominate the study of southeastern Europe, as evidenced in the repetitive identity-obsessed panels of the US-based Association for the Study of Nationalities.

19 For the former, see Stephen Kotkin, '1991 and the Russian Revolution: Sources, Conceptual Categories, Analytical Frameworks', The Journal of Modern History, 70 (1998), 384-425 and his 'The State - Is It Us? Memoirs, Archives, and Kremlinologists', Russian Review, 61, 1 (2002), 35-51. For the latter, see Omnia El Shakry, “History without Documents”: The Vexed Archives of Decolonisation in the Middle East', The American Historical Review, 120, 3 (2015), 920-34.

${ }^{20}$ Family photographs have served as sources in the study of the materiality of socialism, raising questions about property (for example, the centralisation of photographic activity) and censorship. Gilles de Rapper and Durand Anouck, 'Au service du peuple. Coopératives et entreprises de photographes dans l'Albanie communiste', in Ghislaine Gallenga and Laure Verdon, eds., Penser le service public en Méditerranée, Le prisme des sciences sociales (Paris: Karthala, 2017), 219-44; Jolka Nathanaili-Penotet, 'Sur l'autocensure dans l'Albanie totalitaire', Revue Science and Video, 6 (2017), available online: http://scienceandvideo.mmsh.univ-aix.fr/numeros/6/Pages/05.aspx (last visited 8 Oct. 2018). Photographic sources can also help tell a more intimate history of Sino-Albanian exchanges: Anouck Durand, Eternal Friendship (Siglio Press, 2017). Eliot Weinberger's wrong-headed introduction to the volume, however, is best ignored.

21 The number of memoirs published since the early 1990s is extensive - a worthy subject for a separate essay. One of the more celebrated has been At Zef Pllumi's Rrno vetëm për me tregue (Tirana: 55, 2006), which has been translated into English as Live to Tell: A True Story of Religious Persecution in Communist Albania, 1944-1951 (Bloomington, IN: iUniverse, 2008). A view of the ruling elite from the inside is provided in Spartak Ngjela, Përkulja dhe rënia e tiranisë shqiptare: 1957-2010, 2 vols. (Tirana: UET Press, 2011-2013). The 1970s party-directed assault on culture produced long prison sentences and rich memoirs and reflections. Examples include Visar Zhiti's Rrugët e ferrit: burgologjia ime për Spaçin dhe më parë, 2nd ed. (Tirana: Omsca-1, 2012); Ferri i çarë: burgologjia ime për Qafë-Barin dhe më pas, 2nd ed. (Tirana: Omsca-1, 2012) and Maks Velo's Kohë antishenjë (Tirana: Onufri, 2000). 
detail to their cellmates. (Some of the imprisoned officials continued to believe in the communist cause while behind bars.)

The best of these works illuminate the incredible parallel society that the dictatorship unwittingly created - the kind of intergenerational and cross-social class connections it forged through the exercise of violence. Approaching official archives, to which I turn to next, will require an imaginative approach also informed by this important and expanding body of literature.

\section{The Politics of Access}

One reason for the paucity of deeply grounded historical analyses of the dictatorship has been the fact that communist era archives, in particular the records of the highest party organs, were not accessible prior to the early 2000s, or they were accessible to a few people with the right connections. Even as more collections became gradually available, guidelines for access and declassification were not systematically applied in practice. ${ }^{22}$ Not even the inventories of the Central Committee collections, for example, were made freely available until recently. Discouragement of this type worked; many Tirana-based scholars avoided the archives. Moreover, archives have turned into places of political infighting between the country's two major parties ('Democrats' and 'Socialists') and their cronies. Since the position of the director of the state archives has been deemed a political appointment, the person holding it has always been at risk of being removed after parliamentary elections. In fact, majority parties have occasionally used the position as a reward for smaller coalition partners.

Such deep running politicisation has been toxic for the historical profession, which mirrors the infighting. Historians have often fallen into, or have been assumed to be part of, 'camps' roughly corresponding to perceived political loyalties. Most simplistically such camps consist of those deemed to be 'anti-communists' and so-called apologists for the old regime. This has not been helpful in generating new research agendas, but it has helped distribute access to salaries and funds. It is hardly surprising, then, that historical discussion has developed in the form of public polemic. The readership of specialised journals is tiny; much of the back-and-forth over historical problems has taken place in daily newspapers and, increasingly, online. For its part, the press has revelled in the scandalous, bombarding readers with extracts from archival documents on the secret lives of party higher-ups, their supposed mistresses and misdeeds and other clickworthy tabloid headlines. Detached from their historical context, archival extracts - trial records, testimonies extracted under duress from arrested individuals, denunciations, personal letters have fuelled hostile exchanges and counter-accusations of having collaborated with the former regime.

Nothing exemplifies this approach to documents as weapons like the long-standing controversy over the records of the feared security police (Sigurimi $i$ shtetit). Until very recently Sigurimi's files were off-limits to researchers. In fact, even if one somehow got temporary access, it was not possible to work in them in any kind of systematic fashion because a vast amount of the material was completely disorganised. Still, drips of information and rumours about the files have circulated privately and publically for decades, fuelling speculation about what damaging material might be contained there. ${ }^{23}$ Politicians have routinely accused opponents of having

22 A 2003 law on archives ('Për arkivat', Nr. 9154, 6 Nov. 2003) stipulated that documents were to be consulted twenty-five years after they were created. In practice, access has been difficult and uneven. Furthermore, there are additional laws governing access to personal data, which continue to complicate research. Online inventories for some of the collections of the Central State Archives were rolled out in 2017, but they contain gaps and errors.

23 The former director of the Interior Ministry archive has published a study on the history of the security police. Kastriot Dervishi, Sigurimi i shtetit 1944-1991: historia e policisë politike të regjimit komunist (Tirana: 55, 2012). (He also enjoys posting various documents, with brief explanations, on Facebook.) There have also been claims that an unspecified number of files have been destroyed. 
served as Sigurimi informers. Lists of alleged informer 'nicknames' have also circulated online. The obsession over the secretive records reached the point that Albania's parliament recently created a special agency (Autoriteti për informimin mbi dokumentet $e$ ish-Sigurimit të Shtetit) tasked with going through the material and making files accessible.

This controversy has revealed, more than anything, a lack of understanding of how the partystate (and, by extension, its archives) operated. Debates have been framed around the problem of 'publicising' the contents of 'secret' files, rather than elaborating on the specific role of information - its gathering, processing and various uses - at various times in the history of the communist regime. There will be, no doubt, incriminating and embarrassing evidence in these files, as histories of other Eastern Bloc security police agencies have shown. But the reality of the security police's paperwork may be far more mundane than assumed. Sigurimi could be ruthless. It wanted to convince Albanians that it had 'ears' everywhere. It pitted family members against family members. And yet it could also be demonstratively incompetent. For historians in particular, 'transparency' can be no substitute for interpretation. Merely making files public, displaying heavily redacted documents behind glass - as in the recently opened Sigurimi museum in Tirana - does not offer any explanation for how the repressive apparatus actually functioned. Exhibits without context do little to advance knowledge besides lending the false impression of a substantive engagement with the past.

Similarly absent has been a discussion of archives as a process, rather than a place of truths waiting to be brought into the light. The mystery over the Sigurimi files, and more generally the poor handling of archival access, has encouraged the impression of a finely tuned regime with an all-knowing security police. Instead, a history of archiving and their administering bodies over time makes it possible to go beyond the idea of archives as obvious repositories of truth. ${ }^{24} \mathrm{We}$ know that the communist era archives are full of lies. We know that the regime used paperwork people's work and personal biographies, their willing and unwilling written testimonies - as weapons in a battle to identify so-called enemies. The truth of the dictatorship does not reside in any one 'secret' folder to be 'discovered' and made public; its violence cannot properly be understood as divorced from the broader state building history. It becomes necessary, therefore, to think about archives as part of a larger project, carried out formally and informally, to define the state and its subjects.

\section{Archives as History}

How Albania's archives are organised (or not) tells us a great deal about the ambitions and priorities of the party-state, as well as its failures. Three main aspects of this story stand out: the lateness of a comprehensive organisation of state archives, especially given other urgent statebuilding efforts and an unskilled labour force; the far-reaching role of the party apparatus in matters of preservation, interpretation and access and, finally, the impact of the country's unforeseen geopolitical shifts (from Belgrade to Moscow to Beijing) on approaches to the past. These are interconnected issues. An awareness of being latecomers to organised communism and industrialisation permeated the politics of the Party of Labour in the 1940s to 1950s. Intra-state competition over resources under central planning left traces in the archives, too. Squabbles with foreign partners like Yugoslavia and the Soviet Union, additionally, repeatedly raised the problem

\footnotetext{
${ }^{24}$ An implicit strand in the compulsive preoccupation with secret documents, especially high-level deliberations, has been the expectation that some hidden conspiracy awaits to be unearthed, explaining the longevity of communist era functionaries in post-communist politics. For example, a widely shared theory about the collapse of the regime goes something like this: in the late 1980s Eastern Bloc leaders met in Katowice (Poland) to strategise about retaining property and privileges on the eve of the collapse of central planning. Ramiz Alia, Albania's party boss after Hoxha's death in 1985, is said to have received guidelines from Mikhail Gorbachev about how to proceed with such nefarious plans. A 'document' describing this situation has been circulating in various Albanian media for years.
} 
of historical revision. Even a tentative sketch of how recordkeeping became a state matter illustrates how these problems became enmeshed.

The immediate post-war years saw waves of expropriations - houses, small workshops, machines, hidden gold and personal libraries - but a less visible battle also took place over the sorting out of compromising fascist era materials and the adjudication of political loyalty on the basis of personal biographies. From the beginning the party's collections were kept separate from state records, thus reflecting the dual party-state typology of the new regime. ${ }^{25}$ Officials began collecting wartime testimonies and compiling a history of 'resistance' under fascism. Records were placed under the authority of politically trusted personnel within the Central Committee. Established in 1955, the Central Party Archive (Arkivi Qendror i Partisë) documented the history of organised labour in the pre-war period, anti-fascist activism, Comintern's involvement in Albanian affairs and the biographies of important resistance groups. Given the clandestine nature of communist activities during the interwar period, collecting materials and compiling biographical data became especially important for creating a party genealogy, for grounding the party within national history. This imperative became especially important after the split with Yugoslavia in 1948.

By comparison, it took considerably more effort and time to centralise state archives and gather materials into local repositories. Initially, in 1949, a government decision placed the central state archives with the Institute of Sciences, but two years later they were placed under the jurisdiction of the Ministry of Interior. ${ }^{26}$ Instructions went out to ministries and other agencies to make proper room for documentation, emphasising the importance of keeping secret documentation sealed. ${ }^{27}$ Unable to keep up, administrators complained about scarce space. Systematic collection and proper housing of material continued to be a challenge for years, especially among local agencies in the outer districts. ${ }^{28}$ By the mid-1950s a team of investigators, along with a Soviet specialist, surveyed the situation and found it worrisome. Previous government decisions had not worked; local officials kept amassing paperwork in large piles dumped into storage rooms. On some occasions there was not even proper accounting about what paperwork came in and out. The number of personnel entrusted to the task of classifying materials was inadequate. $^{29}$

Such correspondence betrays uncertainty over the proper place for archives within a partystate. Placing the Ministry of Interior in charge reflected concerns over the sensitive nature of the material, but some officials appeared confused about what documents to keep and what to throw away. Since party and defence archives were kept separate from the rest, they were subject to their own guidelines. When it came to state records, however, determining the status of documentation was not always clear. Matters of economic planning, for example, were also supposed

25 Kujtim Nako, Historia e arkivit qendror të Partisë së Punës të Shqipërisë (Tirana: Drejtoria e Përgjithshme e Arkivave, 2004). After the collapse of the communist regime, the party's archives were transferred to the Central State Archives (Arkivi Qendror Shtetëror), where they remain to this day, as a separate unit (Fondi 14/AP). See Dhurata Islami and Kujtim Nako, Shqipëria në Historinë e Luftës së Ftohtë: udhërrëfyes i Arkivit Qendror Shtetëror (Tirana: Drejtoria e Përgjithshme e Arkivave, 2007).

26 'Urdhëresë Nr. 21', 8 June 1949, Arkivi Qendror Shtetëror (Central State Archives, Tirana, hereafter AQSH), Fondi (F.) 507, Viti (V.) 1949, Dosja (Dos.) 1, Fleta (Fl.) 2; 'Vendim, Nr. 479', 18 June 1951, AQSH, F. 507, V. 1951, Dos. 1, Fl. 1.

27 Correspondence between the State Control Commission and the Ministry of Construction, 13 December 1950, AQSH, F. 499, V. 1950, Dos. 20, Fl. 5.

28 As an example, Injac Zamputi described archiving conditions in Shkodër in a letter to Qamil Gavoçi, 2 Sept. 1950, AQSH, F. 507, V. 1950, Dos. 1, Fl. 4-5.

29 'Relacion - shpjegues', n.d., AQSH, F. 507, V. 1955, Dos. 1, Fl. 3. Two years later more critical reports mentioned lost documentation. Ministry of Interior to Office of Prime Minister (Top Secret), 2 Mar. 1957, AQSH, F. 507, v. 1957, Dos. 4, Fl.1. In Krujë, for example, the local executive committee reportedly did not have any type of recordkeeping system in place, despite the government-issued directives. Ministry of Interior to Krujë Executive Committee (Top Secret), 15 Aug. 1957, AQSH, F. 507, v. 1957, Dos. 4, Fl. 16. 
to be confidential. With each five year planning push, officials obsessed over wreckers and saboteurs, which raised the problem of protecting planning data. ${ }^{30}$ Administrators periodically berated their inferiors for either mishandling sensitive correspondence or for forwarding it to persons unauthorised to see it. Throughout campaigns to single out 'enemies' government officials became engrossed with the importance of keeping things secret, even as they created more and more secrets by simply writing more - forwarding ever-increasing amounts of paperwork across agencies.

The party's Politburo tackled the problem of the state archives in late 1960, proposing to move the agency from the Ministry of Interior to the purview of the Council of Ministers. This signalled a shift in thinking about state archives as a cross-agency problem, requiring oversight, but also personnel, technical training and equipment. The new department was envisioned as employing a mix of military and technical personnel. ${ }^{31}$ But as much as government officials pushed, some state organs still lacked proper personnel dedicated to archiving. For example, the Radio Agency (Radio-Difuzioni), the Telegraphic Agency (Agjencia Telegrafike) and the Film Studio (Kinostudio) only had temporary archives where material had already begun to disintegrate. ${ }^{32}$ At the local level, many of the executive councils (këshillat ekzekutive) still lacked proper repositories. Only after repeated warnings from higher-ups did functionaries begin to separate files into folders and arrange the material chronologically.

An investigation into recordkeeping from the State Control Commission brought up the example of the Ministry of Trade, where documents lay on the floor and in a basement, next to cleaning supplies. In another agency the basement storing the documents had flooded during winter, resulting in damaged paperwork. Financial files at the State Bank were reported to be disintegrating due to excessive moisture. ${ }^{33}$ Some records were still scattered around - unsecured - in different locations and in the possession of individuals. ${ }^{34}$ Alarmed, officials insisted that archiving had a 'military, scientific, and techno-scientific' character of utmost importance, but they were also confronted with the simple fact that bureaucratic build-up made centralisation complex. ${ }^{35}$ One proposal mentioned asking Moscow to send a specialist on archives for training purposes, in addition to sending Albanian trainees abroad. ${ }^{36}$ By the middle of 1961, however,

${ }^{30}$ One early 1950s memo, for example, noted that over 95 per cent of the work of the State Planning Commission was either secret or top secret in nature. The correspondence is contained in AQSH, F. 495, V. 1953, Dos. 59, Fl. 1-2.

31 The administrative shuffle also raised questions of hierarchy. Who responded to whom? One proposal was to rank the director of the archives at the level of the office of statistics. For his part, the archive's director argued that his unit had to be placed on the same level as the State Bank. Perhaps this had something to do with the fact that the bank director earned a bigger salary than the chief of statistics. 'Epet mendim mbi projektin e paraqitur nga Drejtori arkivave', 24 Dec. 1960; 'Parashtresë mbi riorganizimin e arkivave të shtetit', 3 Jan. 1961, both in AQSH, F. 490, v. 1961, Dos. 126, Fl. 6-7.

32 'Relacion mbi gjëndjen dhe masat për përmirësimin e punës në sektorin e arkivave shtetërore të R. P. Shqipërisë' (Top Secret), 23 Feb. 1961, AQSH, F. 490, V. 1961, Dos. 126, Fl. 15-20.

33 'Mbi gjendjen e arkivave të përkohëshme të Ministrive, Institucioneve, nd/jeve dhe organizatave ekonomike' (Secret), 10 Feb. 1961, AQSH, F. 490, V. 1961, Dos. 126, Fl. 11-14.

34 'Relacion mbi projekt-vendimin 'Mbi organizimin e arkivave shtetërore', 4 Jan. 1961, AQSH, F. 490, V. 1961, Dos. 55, Fl. 3.

35 A draft proposal asked for more personnel (an increase from sixty-five to 125). The government decision attached fiftyseven chief archivists to various central agencies and local councils. Nevertheless, the central authority was not yet made fully independent; its budget and personnel were still placed under the Ministry of Interior, but the authority was called 'autonomous'. 'Vendim Nr. 109, mbi organizimin e arkivave shtetërore', 21 Apr. 1961, AQSH, F. 490, V. 1961, Dos. 126, Fl. 24-26. Just because a decision was passed, it does not mean that it was promptly executed. When the problem came up again later that year, it turned out that few institutions had followed the guidance. Ministry of Interior to Office of Prime Minister (Secret), 7 Oct. 1961, AQSH, F. 490, V. 1961, Dos. 126, Fl. 35.

36 'Projekt-vendim mbi riorganizimin e arkivave shteterore', n.d., AQSH, F. 490, V. 1961, Dos. 55, Fl. 5-8. The government decision later in the spring, however, did not mention foreign assistance, though it did mention foreign currency funds to purchase needed equipment. As Soviet-Albanian relations continued to deteriorate, it became clear that Tirana could no longer rely on Moscow. 'Vendim Nr. 109', 21 Apr. 1961, AQSH, F. 490, V. 1961, Dos. 126, Fl. 24-26. 
relations between Tirana and Moscow had turned icy, and Soviet specialists soon left Albania. Later that year there was a proposal to convert the vacated Soviet embassy into the archive agency's building, but the prime minister vetoed the idea.

By the early 1960s, then, archiving was no longer understood simply as a problem of storage and security (though it was that, too). It was now seen as a process of assessment and classification, as a way of distinguishing different types of paperwork and attaching different forms of value to documents. This took place in the context of increasingly scarce resources and in the shadow of the political break with Moscow. A scholar working in today's state archives may not immediately see the work that went into this process. But these were procedures worth thinking about - the 1960s parallel effort across agencies to think of the country's post-war bureaucracy as an interconnected whole. Though archives speak with the language of order, the view of a centralised state came about retrospectively. ${ }^{37}$ This invites us to think about what has entered the archives, what is missing there and how 1960s conceptions of governance, authority and value have framed documentation. (What goes where? What should be discarded?) A history of socialist era archiving warns us against assuming all along the presence of a fully formed state. Exposing the administrative messiness of the postwar years, archives can also show how the battle for order became inextricable from the battle for socialism itself.

Centralisation was not an event but a process. More than bureaucratic decrees, it entailed intellectual tasks in making sense of the state as an interconnected thing. Albania's archives are a good place to illustrate how the idea of an orderly state was a historical project, too. More specifically, it might be useful to analyse how conceptions of order - disciplining paperwork and the bureaucrats producing it - interacted with the disquieting disarray of the socialist world after the Sino-Soviet split. This might show how the imperatives of centralisation also became exercises in self-definition, as state bureaucrats came to deal with the clutter they were surrounded by, and how this anxiety about a growing state apparatus took a life of its own, ultimately exploited by the party boss to launch forced shuffling during the 'revolutionary' years (revolucionarizimi i jetës së vendit) of the late 1960s. A ground-level history of these years remains to be written. There will be much of value in the archives to elucidate the important domestic social dynamics. ${ }^{38}$ But my point is that these same archives make it possible to show how internal dynamics were informed by developments in the broader world.

\section{The Local and the Global}

One way to open up Albanian historiography to fresh perspectives is to see interpretative possibilities in the country's Cold War era alignments and schisms: first as the uneasy satellite of Yugoslavia in the mid-1940s, then as an ally of the Soviet Union and the Eastern Bloc and, finally, as China's fiery partner during the 1960s and much of the 1970s. ${ }^{39}$ Beyond these, the Party of Labour maintained ties to various Marxist-Leninist revolutionary movements, fringe groups and armed guerrillas ranging from nearby Italy to Scandinavia and the Iberian Peninsula,

37 Decades later the country's highest scientific authority would claim that the state archives originated in 1944, when party boss Enver Hoxha was said to have recommended the creation of a commission to preserve historical documentation. Akademia e Shkencave e RPSSH, Fjalor enciklopedik shqiptar (Tirana: Akademia e Shkencave e RPSSH, 1985 ), 41.

38 The study of the 'revolutionary' 1960s - particularly from a provincial perspective - would yield important insights on gender dynamics and religion. For indicative overviews, see Nathalie Clayer, 'L'Islam sunnite dans l'espace albanophone XIXe-XXIe siècle', in Oliver Jens Schmitt, ed., Religion und Kultur im albanischsprachigen Südosteuropa (Frankfurt: Peter Lang, 2010), 151-62; Ermira Danaj, 'From Women's Emancipation Model to Fetishism of the Law: Gender in Communist and Post-Communist Albania', in Sofia Aboim and Pedro Vasconcelos, eds., Gender, Sexuality and the Body: Critical Perspectives (Collection of Papers) (Lisbon: Instituto de Ciências Sociais da Universidade de Lisboa, 2014), 48-58.

39 Albania's 'cultural revolution' of the late 1960 s, for example, can serve as a productive angle into the paradoxes of SinoAlbanian relations. See Ylber Marku, 'China and Albania: The Cultural Revolution and Cold War Relations', Cold War History, 17, 4 (2017), 367-83. 
and all the way to the Congo and the Brazilian rainforest. ${ }^{40}$ The scope of this form of revolutionary 'globalism' has only recently become visible. Each of these partnerships left behind traces in the archives (especially within the party's foreign department), which contain documents in Serbo-Croatian, Russian, French (the language of party business prior to the state-supported expansion of Russian in the 1950s), Chinese, Korean and other languages.

It is possible to capture socialism's global footprint precisely in the fact that an international archive came about in one tiny corner of Southeastern Europe. Socialist states themselves encouraged these kinds of transnational contacts early on, but the ideological squabbles of the 1960 s produced new contacts and communications on a large scale. At the same time, precisely because recordkeeping took a while to become centralised, how the history of these international ties ought to be systematised turned into an ideologically significant problem. Each of the country's political alliances had a beginning and an end, and so party ideologues were confronted, repeatedly, with the problem of placing these relationships into a proper analytical frame. Why did Belgrade stray in the late 1940s? Why did Khrushchev betray Stalin in 1956? Why had the communist world splintered? And then, years later: why did the Chinese choose to welcome US president Richard Nixon? Why had revolution failed in the decolonised world? ${ }^{41}$

It became urgent to rewrite the recent past, to reframe socialist internationalism through the unavoidable problem of geopolitics. Writing such a history was not merely a formal task; it became a matter of self-definition on a large scale. In so doing, officials insisted that it was impossible to detach the party's history from national history. For example, the 1948 schism with Belgrade was followed by efforts to write Yugoslavia out of earlier history - withdrawing textbooks, culling speeches, cleansing library holdings. ${ }^{42}$ A decade later, the rift with Moscow during the Sino-Soviet crisis would similarly require a cultural reorientation. Central Committee higherups urged Albanians to continue to celebrate the heritage of Stalinism but also denounce the 'revisionism' that had taken root under Khrushchev (and then his successors, too). The centralisation of state archives and the establishment of party history initiatives thus coincided. What has been taken out of records, or redacted? What kind of work was necessary to remix the historical record, in order to serve the evolving needs of a party that saw itself as embattled? Reading archives as an ongoing preoccupation over time and in conjunction with other institutions means looking for evasions, contradictions and gaps.

More concretely, such analysis might pursue the history of neglected institutions, especially those lower than the office of the party boss or the Politburo, which are the obvious places for histories of the regime. Consider, for example, the Institute of Marxist-Leninist Studies, which was the vehicle through which many up and coming party elites made their names. Attached to the party Central Committee, the Institute served as a 'theoretical centre' tasked with promoting the official line - the regime's ideological, economic and organisational orientation. ${ }^{43}$ Its history

40 Nicola Pedrazzi, L'Italia che sognava Enver: partigiani, comunisti, marxisti-leninisti: gli amici italiani dell'Albania popolare (1943-1976) (Nardò: Besa, 2017); Ylli Molla, Guerilas made in Albania: historia e Arafatit, Kabilës, Lulës, Amazonas dhe luftëtarëve nga 11 shtete, që u përgatitën politikisht dhe ushtarakisht nga pedagogët shqiptarë (Tirana: Botart, 2016); Carlos Hugo Studart Corrêa, 'Em algum lugar das selvas amazônicas: as memórias dos guerrilheiros do Araguaia (1966-1974)', $\mathrm{PhD}$ dissertation, Universidade de Brasília, 2013.

41 Then, after Hoxha's death in 1985, as the Tirana-based historian Edon Qesari has elaborated, an additional conceptual problem became reframing the 'recent past' in the shadow of the dead leader. Edon Qesari, 'La storiografia contemporanea albanese e lo studio della storia recente. Gli anni del "passaggio epocale” (1985-1992)', in Antonio D'Alessandri and Armando Pitassio, eds., Dopo la pioggia: gli stati della ex Jugoslavia e l'Albania (1991-2011) (Lecce: Argo, 2011), 51-64.

42 The country's foreign relations also provide a good basis for comparative study, including of mechanisms of the leader's cult. See Stanislav Sretenović and Artan Puto, 'Leader Cults in the Western Balkans, 1945-1990: Josip Broz Tito and Enver Hoxha', in Balázs Apor, Jan C. Behrends, Polly Jones and E. A. Rees, eds., The Leader Cult in Communist Dictatorships: Stalin and the Eastern Bloc (Basingstoke: Palgrave Macmillan, 2004), 208-23.

43 Established in 1956, it was initially called the Institute of the History of the Party of Labor of Albania. In February 1966 the agency was renamed Institute of Marxist-Leninist Studies at the Central Committee of the Party of Labor of Albania. 
can be particularly revealing since it was also responsible for publishing select primary sources from the archives and preparing official party histories. Moreover, it collaborated with other institutions (like the State University and the Academy of Sciences) on proceedings of national conferences on topics like the National Liberation War, the development of social sciences, constitutional matters, class war and the international order. ${ }^{44}$ In short, the Institute of MarxistLeninist Studies was one of the official mechanisms for elaborating a 'scientific' socialist understanding of the wider world - an essential objective after the Sino-Soviet split.

Another key task of the Institute was to publish party leader Enver Hoxha's voluminous collected Works (Vepra), which first came out in 1968 and reached over seventy volumes by the early 1990s. ${ }^{45}$ We are missing a comprehensive study of how the party leader's publications - a central element of his developing personality cult - came about. ${ }^{46}$ His books continue to be consulted by foreign scholars, in itself a reflection of the money and time that the party apparatus put into translating them into foreign languages and disseminating them around the world. Many of Hoxha's titles, including his so-called diaries, are based on archival documents, but they also often rearrange chronologies, distort the bigger picture and leave out important details. They are pastiches. One can imagine a history of the apparatus that came about to collect and edit this data, to sanction translations from and into Russian (which remained a key language well after the Soviet-Albanian schism in 1960-1), to select the 'right' historical evidence for each task, to intervene in texts and to order and execute translations into major Western languages with the help of foreign allies.

More broadly, works that explore the inner workings of such institutions can shed light on the paradoxes of socialism's waning years. Too often, Albania's 1970s and 1980s are marked as a period of 'isolation'. And it is true that the regime's paranoia about outside interferences reached a peak: the 1976 constitution, for instance, confirmed Marxist-Leninism as official ideology and forbade credits from or concessions to foreign companies or 'capitalist, bourgeois and revisionist states'. The effects were deeply felt throughout the 1980s, as food lines grew and the economy caved in. But talk of the country being 'sealed' from the outside world obscures the fact that isolationism also encourages a constant mapping of the outside world. Back in the 1960s the Institute of Marxist-Leninist Studies had been a vehicle for popularising Mao Zedong's writings in the Albanian language. ${ }^{47}$ A decade later it continued the work of showcasing Hoxha as a major voice in international Marxism-Leninism, in addition to distributing foreign-language translations of the party's history. ${ }^{48}$ Radio Tirana, founded with Italian technical assistance in the late 1930s and boosted through Soviet and Chinese technology, became by the 1970s a kind of 'guerrilla' global revolutionary voice, too. A younger generation of Albanians, especially in the largest cities, continued to find creative ways to receive and engage with Western cultural signals. ${ }^{49}$

44 Among many examples: Dokumente kryesore të Partisë së Punës të Shqipërisë, 8 vols. (Tirana: Instituti i Studimeve Marksiste-Leniniste pranë KQ të PPSH-së, 1960-1986); Probleme të zhvillimit të sotëm botëror: tetor 1978 (Tirana: 8 Nëntori, 1978); Konferenca shkencore për problemet e kushtetutës: 5-7 shkurt (Tirana: 8 Nëntori, 1976); Historia e luftës antifashiste nacionalçlirimtare të popullit Shqiptar, 1939-1944 (Tirana: 8 Nëntori, 1975); Konferenca kombëtare e studimeve shoqërore: nëntor 1969 (Tirana: Naim Frashëri, 1970).

45 A proper non-journalistic biography of Enver Hoxha is not yet available.

46 One author has written that the production of Hoxha's Vepra 'was enabled by a collective enterprise, including the work of ghostwriters, who besides payment had no other right but to remain silent'. Leka Ndoja, Tjetërsimi $i$ veprës intelektuale gjatë komunizmit në Shqipëri, 1944-1990 (Tirana: ISKK, 2013), 91.

47 Elidor Mëhilli, 'Mao and the Albanians', in Alexander C. Cook, ed., Mao's Little Red Book: A Global History (Cambridge: Cambridge University Press, 2014), 165-84.

48 Examples include: History of the Party of Labour of Albania (Tirana: Naim Frashëri, 1972); Istoria albanskoi partii truda: 1966-1980 (Tirana: 8 Nëntori, 1981); Histoire du Parti du travail d'Albanie (Tirana: 8 Nëntori, 1982) and Geschichte der Partei der Arbeit Albaniens (Tirana: 8 Nëntori, 1982).

49 For important insights not yet fully developed in Albanian-language historical scholarship, see Ardian Vehbiu, Sende që nxirrte deti: ese (Tirana: Dudaj, 2013). 
Such studies could expose the limits of concepts like 'isolation' and 'openness' in analysing the variegated world of socialism, particularly in its later years. These terms do little to capture the paradoxes of a globalised socialism operating on many fronts and at multiple scales. Albania's regime spoke aggressively but was also deeply insecure. It continued to profess internationalism abroad even as it became increasingly paranoid about ideological contamination. It did not hesitate to execute individuals and erase their bodies from history, but it was also profoundly unsettled by Western texts, 'capitalist' radio signals and foreign television broadcasts. It pursued a path that does not fit within standard narratives of socialist reformism. And so when we look at places that don't fit general histories, we call them anomalies. But it might be a good idea to start from the 'anomalies' as way of testing explanatory frameworks. 'Anomalies' force us to think about the trap of mistaking the choices of others for pathologies.

This history is worthy of study in its own right, but Albania's past also invites us to rethink the progression from Stalinism to 'normalised' socialism to regime collapse. Such choices of periodisation have analytical implications. A diplomatic history of the Sino-Soviet split might pursue party elite perceptions, for example, but a cultural history of the split can illustrate how diplomatic rifts also create room for manoeuvre and new modes of self-fashioning. To go against Moscow in the 1960s, after all, was to try and figure out new ways of speaking about the present and the future of socialism. Insights from a broader range of sources from this era - scientific and technical agreements, cultural exchanges with China, not-always-successful forays to Cuba and Africa - can reveal how ideology turned into a kind of currency for smaller actors to navigate this changing geography of socialism - one that Moscow and Beijing helped shape but which they could not fully control. This latter point goes against the tendency in Cold War scholarship to fixate on Soviet or Chinese 'successes' and 'failures' in other places.

As global history overlaps more and more with the history of capitalism, finally, it is important for all kinds of historians of socialism to continue to demonstrate how anti-capitalism has long produced contacts and practices on a global scale. Parts of this history are also the places that have resisted internationalisation, and those rulers who pursue the allure of 'self-reliance' in a world dominated by big capital. Here, Albania's historians have an opportunity to connect their work to broader ongoing debates about how illiberal regimes exploit geopolitical anxiety; how they strategically deploy appeals to a supranational sphere (communist-led revolution fifty years ago; 'Europe' these days). One challenge will be to give due attention to local particularities without perpetuating the idea of the country's uniqueness in the world. ${ }^{50}$ In defining itself, Albania's regime favoured a limited range of conceptual categories: heroic endurance, painful betrayal by foreign powers, subjugation and a do-it-alone spirit. It is important to continue to explain how these terms became operative. After all, strange though this militancy might sound in retrospect, such terms are hardly absent from politics in today's world.

Cite this article: Mëhilli, E. 2019. Documents as Weapons: The Uses of a Dictatorship's Archives. Contemporary European History 28: 82-95. doi: 10.1017/S0960777318000656

50 Comparative work remains the exception. A recent example: Adrian Brisku, Bittersweet Europe: Albanian and Georgian Discourses on Europe, 1878-2008 (New York: Berghahn Books, 2013), esp. 108-52. 